\title{
MLH1 wt Allele
}

National Cancer Institute

\section{Source}

National Cancer Institute. MLH1 wt Allele. NCI Thesaurus. Code C50991.

Human MLH1 wild-type allele is located in the vicinity of 3p21.3 and is approximately 57 $\mathrm{kb}$ in length. This allele, which encodes DNA mismatch repair protein Mlh1, plays a role in DNA mismatch repair. Aberrant alleles are associated with colon, endometrial and stomach cancers. Further, the defects in MLH1 are a cause of hereditary non-polyposis colorectal cancer. 